\title{
Determining the optimal dose of virginiamycin for ruminal parameters and performance of Nellore cattle on pasture
}

\section{Determinação da melhor dose resposta de virginiamicina nos parâmetros ruminais e desempenho de bovinos Nelore a pasto}

\author{
João Alexandrino Alves Neto ${ }^{1}$; Ivanna Moraes de Oliveira ${ }^{2 *}$; Matheus Henrique \\ Moretti $^{3}$; Paloma Helena Gonçalves ${ }^{1}$; Michele Aparecida Prado Alves ${ }^{4}$; Juliano \\ José de Resende Fernandes ${ }^{5}$; Flávio Dutra de Resende ${ }^{6}$; Gustavo Rezende Siqueira ${ }^{6}$
}

\begin{abstract}
There are no studies evaluating the virginiamycin (VM) doses under tropical conditions. So, the present study was conducted to evaluate the optimal dose of VM for growing Nellore bulls on tropical pasture. Two experiments were conducted. The first experiment, one hundred and two Nellore bulls (307 \pm 25 $\mathrm{kg}$ body weight [BW]; 22 months) were used. Animal performance was evaluated using a randomized block design, with group as experimental unit $(\mathrm{n}=8 ; 12$ animals each). The second experiment, a double $4 \times 4$ Latin square, eight animals were used to evaluate the ruminal parameters. Four doses were evaluated: $0,35,55$, and $75 \mathrm{mg}$ VM per $100 \mathrm{~kg} \mathrm{BW}$. The average daily gain $(\mathrm{P}=0.08)$ and carcass gain $(\mathrm{P}=0.05)$ exhibited a trend of quadratic behavior. An increased dose of VM did not affect supplement intake $(\mathrm{P}=0.64)$, rumen $\mathrm{pH}(\mathrm{P}=0.96)$, acetate: propionate ratio $(\mathrm{P}=0.73)$, or the total concentration of volatile fatty acid $(\mathrm{P}=0.63)$. The concentration of rumen ammonia nitrogen exhibited a quadratic effect $(\mathrm{P}=0.01)$. A quadratic behavior was found for volatile fatty acid, except for propionate, which presented linear behavior $(\mathrm{P}=0.03)$. In conclusion, the dose of $47 \mathrm{mg} \mathrm{VM}$ per $100 \mathrm{~kg} \mathrm{BW}$ is recommend for growing Nellore bulls on tropical pasture.
\end{abstract}

Key words: Additive. Non- ionophores. Supplement intake. Tropical grass.

\section{Resumo}

Em condições tropicais não existem estudos avaliando doses de virginiamicina (VM). Dessa forma, o presente estudo foi conduzido para avaliar a dose ótima de VM para bovinos Nelore recriados em pasto tropical. Dois experimentos foram conduzidos. No Experimento 1 foram usados 102 bovinos Nelore não castrados, com peso corporal (PC) inicial de $307 \pm 25 \mathrm{~kg}$ e 22 meses de idade. As variáveis de desempenho foram avaliadas em blocos inteiramente casualizados, sendo o grupo a unidade experimental $(\mathrm{n}=8 ; 12$ animais cada). No Experimento 2 foram utilizados 8 animais em quadrado latino duplo para

1 Discentes, Curso de Mestrado, Programa de Pós-Graduação em Zootecnia, Universidade Estadual Paulista, UNESP, Jaboticabal, SP, Brasil. E-mail: joao_medveterinaria@hotmail.com; loma.helena@hotmail.com

2 Pesquisadora, Pós-Doutorado, UNESP, Jaboticabal, SP, Brasil. E-mail: imoraesdeoliveira@yahoo.com.br

3 Gestor Técnico de Bovinos de Corte, Agroceres Multimix, Rio Claro, SP, Brasil. E-mail: matheus.moretti@agroceres.com

4 Discente, Curso de Graduação, Centro Universitário da Fundação Educacional de Barretos, UNIFEB, Barretos, SP. E-mail: alves_micheleprado@hotmail.com

5 Prof., Universidade Federal de Goiás, UFG, Goiânia, Brasil. E-mail: julianojrf@ufg.br

6 Profs. e Pesquisadores, UNESP, Jaboticabal, SP, Brasil; Agência Paulista de Tecnologia dos Agronegócios, APTA, Colina, SP, Brasil. E-mail: flaviodutraderesende@gmail.com; siqueiragr@gmail.com

* Author for correspondence 
avaliação dos parâmetros ruminais. Foram avaliadas 4 doses de VM: 0,35 , 55, e 75 mg VM para cada $100 \mathrm{~kg}$ PC. $\mathrm{O}$ ganho médio diário $(\mathrm{P}=0.08)$ e o ganho em carcaça $(\mathrm{P}=0.05)$ apresentaram tendência de comportamento quadrático. $\mathrm{O}$ aumento na dose de VM não afetou o consumo de suplemento $(\mathrm{P}=0.64)$, $\mathrm{pH}$ ruminal $(\mathrm{P}=0.96)$, relação acetato: propionato $(\mathrm{P}=0.73)$ e a concentração total de ácidos graxos voláteis $(\mathrm{P}=0.63)$. A concentração de nitrogênio amoniacal ruminal apresentou efeito quadrático $(\mathrm{P}=$ 0.01). Comportamento quadrático foi observado para todos os ácidos graxos voláteis, exceto propionato, o qual apresentou comportamento linear $(\mathrm{P}=0.03)$. Em conclusão, a dose de $47 \mathrm{mg} \mathrm{VM} / 100 \mathrm{~kg}$ PC é recomendada para bovinos Nelore recriados em pastos tropicais.

Palavras-chave: Aditivo. Consumo de suplemento. Não-ionóforos. Pastagem tropical.

\section{Introduction}

Under tropical conditions, the developing of efficient pasture-based livestock production systems is essential due to the extent of agriculture, territorial areas, and the need for low-cost food production (MCMANUS et al., 2016). In these systems, supplementation strategies have been increasingly implemented to avoid seasonality of forage production (MORETTI et al., 2013; ROTH et al., 2013). The use of additives may further enhance the production and performance of beef cattle on tropical pastures (BERNDT; TOMKINS, 2013).

In livestock production systems, the use of growth-promoting feed additives offers significant advantages, since increasing the efficiency of nutrient utilization (BERNDT; TOMKINS, 2013). Furthermore, greater efficiency implies reduced waste and positive environmental impact (BERNDT; TOMKINS, 2013). Additionally, in livestock grazing systems, the vehicle used to supply additives is the supplement. Therefore, the use of growth promoters that do not restrict supplement intake and ensure a correct consumption of the recommended dose need attention. Ionophores, especially monensin, typically reduce intake (BENATTI et al., 2017). Virginiamycin (VM) is another growth promoter, an antibiotic that causes bacteriostatic or even bactericidal effect, mainly against gram-positive bacteria (GUO et al., 2010). For grazing animals, VM may be an alternative additive, since it has shown satisfactory results with no reduction or modification in supplement intake (FIEMS et al., 1992).
The first study in Brazil using VM for grazing Nellore cattle demonstrated that this additive is a potential antimicrobial for animals reared on pasture (GOULART, 2010). Studies designed to evaluate the optimal VM dose in feedlot-finished cattle (ROGERS et al., 1995) and cattle grazing on winter pastures (FIEMS et al., 1992) have already been performed. However, there are no studies evaluating the optimal dose-response to $\mathrm{VM}$ in Nellore bulls grazing on tropical pastures. So, the objective of this study was to evaluate the optimal dose of VM for Nellore bulls grazing on tropical pasture during the rainy season. The hypothesis of this study is that VM increases the performance and affects the ruminal parameters in Nellore on pasture.

\section{Materials and Methods}

This study was approved by the Ethics Committee on the Use of Animals (CEUA) of the Universidade Estadual Paulista, Campus Jaboticabal (Protocol number 013944/13). All procedures have been conducted in accordance with the Brazilian Guidelines for the Care and Use of Animals for Scientific and Educational Purposes (CONCEA, 2013). The experiment was conducted at the Research Unit of the Agência Paulista de Tecnologia dos Agronegócios (APTA), Colina (20 $43^{\prime} 05^{\prime \prime} \mathrm{S}$ and $48^{\circ} 32^{\prime} 38^{\prime \prime} \mathrm{W}$ ), São Paulo, Brazil, from December 9 to March 27 during the rainy season.

The study evaluated the performance of Nellore bulls ( $\mathrm{n}=102 ; 307 \pm 25 \mathrm{~kg} ; 22$ months) receiving different VM doses. Of these, six animals $(n=6)$ were slaughtered at the beginning of the experiment 
to evaluate the initial hot carcass weight (HCW) of the remaining animals. The remaining animals $(\mathrm{n}=96)$ were weighed, dewormed using $1 \%$ Ivermectin (Ivomec, Merial, Paulínea, São Paulo, Brazil), identified with a numbered plastic earring, and randomly assigned to one of the four treatment groups. To evaluate rumen parameters, eight cannulated Nellore bulls of similar age and mean initial BW to the performance animals were used.

All animals received the same diet (pasture and protein supplement provided daily at $13 \mathrm{~h} 00$ in the amount of $1 \mathrm{~g} \mathrm{~kg} \mathrm{BW}^{-1}$ per day), whereas the concentration of $\mathrm{VM}\left(\operatorname{Vmax}^{\circledR} 10 \%\right.$, Phibro, Guarulhos, São Paulo, Brazil) varied to constitute the treatments as follows: without VM (VM0); 35 mg VM per $100 \mathrm{~kg}$ BW (VM35); 55 mg VM per $100 \mathrm{~kg} \mathrm{BW}$ (VM55), and $75 \mathrm{mg} \mathrm{VM}$ per $100 \mathrm{~kg}$ BW (VM75) (Table 1). The virginiamycin used is a mixture of two distinct chemical compounds, a peptolid, with molecular weight 525 (factor $\mathrm{M} 1, \mathrm{C}_{28} \mathrm{H}_{35} \mathrm{~N}_{3} \mathrm{O}_{7}$ ) and a macrocyclic lactone, with molecular weight 823 (factor $\mathrm{S} 1, \mathrm{C}_{43} \mathrm{H}_{49} \mathrm{~N}_{7} \mathrm{O}_{10}$ ). Body weight of the experimental animals was regarded as almost the same, and the amount of VM supplements was based on the averaged weight of the group. The main purpose of the supplement was to promote the total intake and to guarantee complete ingestion of VM doses, as recommended.

Table 1. Supplement composition (dry matter basis) supplied to Nellore bulls receiving different doses of virginiamycin (VM) and grazing on Panicum maximum 'Tanzania' in the rainy season.

\begin{tabular}{lcccc}
\hline \multirow{2}{*}{ Ingredients (\%) } & \multicolumn{4}{c}{ Supplements $^{1}$} \\
\cline { 2 - 5 } & $\mathrm{VM0}^{2}$ & VM35 & VM55 $^{2}$ & VM75 $^{2}$ \\
\hline Ground corn & 25 & 25 & 25 & 25 \\
Soybean meal & 17.5 & 17.5 & 17.5 & 17.5 \\
Pelleted citrus pulp & 10.1 & 9.75 & 9.55 & 9.35 \\
Mineral nucleus & 38.4 & 38.4 & 38.4 & 38.4 \\
Urea & 9.0 & 9.0 & 9.0 & 9.0 \\
Vmax $^{\circledR} 10 \%$ Phibro $^{3}$ & 0.0 & 0.35 & 0.55 & 0.75 \\
\hline
\end{tabular}

${ }^{1}$ Nutritional level of the supplements $(\%)=$ crude protein 38 , non-protein nitrogen 25 , calcium $4-6$, phosphorous 3 , magnesium 0.5 , zinc 0.1846 ; manganese 0.515 ; copper 0.423 ; fluor 0.273 ; iodine 0.73 ; sodium 0.61 ; cobalt 0.34 ; sulfur 0.10 ; and selenium 0.73 ${ }^{2} \mathrm{VM} 0=0 \mathrm{mg}$ VM per $100 \mathrm{~kg}$ body weight $(\mathrm{BW})$; VM35 = $35 \mathrm{mg}$ VM per $100 \mathrm{~kg} \mathrm{BW}$; VM55 = 55 mg VM per 100 $\mathrm{kg} \mathrm{BW}$; VM75 = $75 \mathrm{mg}$ VM per $100 \mathrm{~kg} \mathrm{BW}$.

${ }^{3}$ Guaranteed composition of $\operatorname{Vmax}^{\circledR} 10$ Phibro $=100 \mathrm{~g}$ of VM per $\mathrm{kg}$ of product.

The experimental area was composed by eight rotational stocking management systems (3 ha each). Each system consisted of three paddocks (1 ha each) of Panicum maximum 'Tanzania', with drinkers and feeding troughs for the supplements in each paddock. The drinkers had a capacity of 1500 $\mathrm{L}$ and the linear feeding trough space per animal was $30 \mathrm{~cm}$. The grazing cycle consisted of 27 days, nine days of grazing and 18 days of paddock rest. Four grazing cycles were completed. The eight rotational grazing systems were grouped into two blocks of four grazing systems. The four treatments were randomized within each block. To reduce the effect of pasture, since there were only two groups per treatment, groups within the same block changed the rotational grazing system at the end of each grazing cycle (MOREIRA et al., 2017; SANTANA et al., 2015, 2017). Consequently, groups within each block passed through all four grazing systems.

At the beginning of each grazing cycle, forage mass was estimated using the double sampling method (SOLLENBERGER; CHERNEY, 1995). To 
evaluate the quantitative and structural components of sward canopy, samples were collected at the average height of each paddock and divided into four fractions: green stem, green leaf, dead/ senescent stem, and dead/senescent leaves. To estimate the nutritional value of the pasture, handplucked samples were collected at the beginning of each grazing cycle (DE VRIES, 1995). The samples were dried in an oven with forced air ventilation at $55^{\circ} \mathrm{C}$ for $72 \mathrm{~h}$, and then ground using a Wiley knifemill to pass through a $1 \mathrm{~mm}$ sieve.

Dry matter ([DM], method 934.01), mineral matter (method 942.05), crude protein ([CP], method 978.04), and ether extract (method 920.39) contents were measured (AOAC, 1995). The content of neutral detergent fiber and acid detergent fiber was evaluated by sequential analysis as described by Robertson and Van Soest (1981) using a TECNAL ${ }^{\circledR}$ TE-149 fiber analyzer (Piracicaba, São Paulo, Brazil). Cellulose was solubilized with $72 \%$ sulfuric acid, and lignin content was obtained as the difference (GOERING; VAN SOEST, 1970). In vitro true digestibility of DM was determined as described by Van Soest and Robertson (1985). Indigestible neutral detergent fiber content was evaluated using non-woven textile bags (100 g per $\mathrm{m}^{2}$ ) incubated in rumen by 240 hours (VALENTE et al., 2011) (Table 2).

Table 2. Mean of quantitative and qualitative characteristics of Panicum maximum 'Tanzania' pasture used during the growing phase of Nellore bulls fed different doses of virginiamycin in the rainy season.

\begin{tabular}{lcc}
\hline Item $^{1}$ & Mean & SEM $^{2}$ \\
\hline Quantitative Characteristics & & 543 \\
\hline Mass of forage (kg DM ha' ${ }^{-1}$ & 8549 & 0.01 \\
Green Leaf: Green stem & 0.70 & 1.64 \\
Green leaf (\%) & 35.9 & 1.73 \\
Green stem (\%) & 51.1 & 0.11 \\
Senescent material (\%) & 13.0 & \\
\hline Qualitative Characteristics & & 0.79 \\
\hline Crude protein (\% DM) & 11.0 & 0.15 \\
Ether extract (\% DM) & 1.90 & 0.83 \\
Neutral detergent fiber (\% DM) & 70.1 & 0.87 \\
Acid detergent fiber (\% DM) & 34.6 & 0.70 \\
Lignin (\% DM) & 8.43 & 0.27 \\
Ashes (\% DM) & 8.50 & 0.46 \\
Digestible organic matter (\% DM) & 77.8 & 8.90 \\
Crude protein: DOM (g Crude protein: kg DOM) & 141 & 0.91 \\
Non-protein nitrogen (\% TN) & 252 & 4.10 \\
Neutral detergent insoluble nitrogen (\% TN) & 49.0 & 1.54 \\
Acid detergent insoluble nitrogen (\% TN) & 13.0 & 2.89 \\
In vitro DM digestibility (\% DM) & 68.2 & \\
\hline
\end{tabular}

${ }^{1} \mathrm{DM}=$ dry matter; $\mathrm{DOM}=$ digestible organic matter; $\mathrm{TN}=$ total nitrogen.

${ }^{2} \mathrm{SEM}=$ Standard error of the mean. 
Supplement intake was calculated as the provided amount per day. The supplement provided daily was entirely consumed, then the doses of VM for each treatment was effectively consumed as recommended. Intermediate weights were taken every 27 days, at the end of each grazing cycle, obtained the BW without fasting. This BW without fasting were used to adjust the amount of supplement provided in each grazing cycle. The initial and final fasting BW of the animals was used to calculate the average daily gain. Animals were weighed following a $16 \mathrm{~h}$ fasting from solids and liquids.

At the beginning $(n=6)$ and at the end of the experiment $(n=64)$, animals were slaughtered according to RIISPOA standards in a Minerva Foods ${ }^{\circledR}$ slaughter house, which is under the Federal Inspection Service and located $20 \mathrm{~km}$ from the research facility (Barretos, São Paulo, Brazil). It is worthwhile to note that at the end of the experiment, the animals did not reach the slaughter BW, because they were still in their growing phase. Therefore, representative animals of each treatments were selected to determine their carcass gain. The initial HCW of all animals was obtained using the equation: $y=0.4349 x+23.595, r^{2}=0.96$, generated from the relationship between fasting $\mathrm{BW}$ and HCW, where $x$ is the initial fasting BW and $y$ is the initial HCW estimated in kilograms. The final dressing percentage was obtained using the formula: dressing percentage $=($ final $\mathrm{HCW} \div$ final $\mathrm{BW}) \times 100$. The carcass gain was obtained by applying the formula: carcass gain $=($ final $\mathrm{HCW}-$ initial $\mathrm{HCW}$ ) $\div$ (number of days of the experiment period). The carcass transfer was calculated using the formula: carcass transfer $=[($ final HCW - initial $\mathrm{HCW}) \div$ (final fasting BW - initial fasting BW)] $\times$ 100, adapted from Sampaio et al. (2017).

Rumen fluid samples were collected on day 27 of each experimental period at $0,6,12$, and $18 \mathrm{~h}$ after supplementation. The samples were collected at ventral side of the rumen, homogenized, and then filtered through a double-layer fabric for extraction of the rumen fluid. The $\mathrm{pH}$ was determined immediately after collection using a Digimed ${ }^{\circledR} 23$ DM pH meter (Campo Grande, Mato Grosso do Sul, Brazil). A $50 \mathrm{~mL}$ aliquot of rumen fluid was acidified using $1 \mathrm{~mL}$ sulfuric acid (1:1) for the analysis of rumen ammonia nitrogen performed by a colorimetric assay according to the protocol described by (WEATHERBURN, 1967), and a $50 \mathrm{~mL}$ aliquot was immediately frozen to assess volatile fatty acid concentration (acetate, propionate, butyrate, valerate, isobutyrate, and isovalerate) by gas chromatography following a method described by (ERWIN et al., 1961).

Forage intake evaluation was made from day 14 to 24 of each period ( 7 days for adaptation and 4 days for feces collections at $6,10,14$, and $18 \mathrm{~h}$, respectively). The chromium oxide was provided in the amount of $10 \mathrm{~g}$ per animal per day at $16 \mathrm{~h} 00$. Feces were collected from fresh samples on the ground right after defecation, avoiding soil contamination. Fecal samples were evaluated for chromium oxide content by using atomic absorption (WILLIAMS et al., 1962). The indigestible neutral detergent fiber was quantified in the hand-plucked samples (DE VRIES, 1995) and feces samples collected on day 2 and 4 of the feces collection.

To evaluate animal performance, a randomized block design was used and the rotational stocking management systems were used as the blocking factor. The adopted experimental units were groups ( $\mathrm{n}=8 ; 12$ animals each), with two groups per treatment. The model adopted was $\mathrm{Y}_{i j k}=\mu+$ $\mathrm{T}_{i}+\mathrm{B}_{j}+\mathrm{e}_{i j k}$, where $i j k=$ observation of the effect of treatment $i$ in block $j ; \mu=$ general mean; $\mathrm{T}_{\mathrm{i}}=$ effect of the treatment; $\mathrm{B}_{j}=$ effect of the blocking factor $j$, and $\mathrm{e}_{i j k}=$ random error associated with each observation.

To evaluate ruminal parameters, a double $4 \times 4$ Latin square design was used. The model used was: $\mathrm{Y}_{i j k m}=\mu+\mathrm{T}_{i}+\mathrm{Q}_{j}+\mathrm{A}_{k(j)}+\mathrm{P}_{m}+\mathrm{e}_{i j k m}$, where $\mathrm{Y}_{i j k m}=$ observation of treatment $i$ in square $j$, in animal $k$ inside square $j$, in period $m ; \mu=$ general mean; $\mathrm{T}_{i}=$ 
effect of treatment $i ; \mathrm{Q}_{j}=$ effect of Latin square $j$; $\mathrm{A}_{k(j)}=$ effect of animal $k$ within square $j ; \mathrm{P}_{m}=$ effect of period $m$, and $\mathrm{e}_{\mathrm{ijkm}}=$ random error associated with each observation.

The effect of the VM dose was evaluated by contrast analysis using orthogonal polynomials to determine the degree of the polynomial function that best fit the doses used. Once the behavior was determined, the coefficients of the resulting polynomial function were estimated using the same statistical model of contrast analysis. To obtain the optimal dose-response to $\mathrm{VM}$, an equation was derived according to the response variable and set it to zero. All data were submitted to analysis of variance for mixed models using PROC MIXED of SAS. For ruminal parameters, the data were analyzed as repeated measures over time using the repeated option of SAS. Different structures of variance and covariance matrices for the residue were tested to determine the structure that best fit each trait. Matrices for each variable were chosen according to the Bayesian Information Criteria (BIC). Significance was established at $\mathrm{P}<0.05$ and trends were defined as $0.05 \leq \mathrm{P}<0.10$.

\section{Results}

Average daily gain $(\mathrm{P}=0.08)$ and carcass gain $(\mathrm{P}$ $=0.05$ ) exhibited a trend of quadratic behavior, with the maximum values being observed at dose of 47 mg VM per $100 \mathrm{~kg}$ BW. Final dressing percentage $(\mathrm{P}<0.01)$ and carcass transfer $(\mathrm{P}=0.02)$ exhibited a quadratic behavior, with the maximum values being observed at doses of 37 and $35 \mathrm{mg}$ VM per 100 $\mathrm{kg}$ BW, respectively. The VM doses used did not affect the final $\mathrm{BW}$ of the animals $(\mathrm{P}=0.26)$. The maximum values were obtained from the equations derived from the treatment results (Table 3 ).

Table 3. Intake and performance of Nellore bulls fed different doses of virginiamycin (VM) during the growing phase on Panicum maximum 'Tanzania' pastures in the rainy season.

\begin{tabular}{|c|c|c|c|c|c|c|c|}
\hline \multirow{2}{*}{ Item } & \multicolumn{4}{|c|}{ Virginiamycin Dose $^{1}$} & \multirow{2}{*}{$\mathrm{SEM}^{2}$} & \multicolumn{2}{|c|}{ Contrasts $^{3}$} \\
\hline & VM0 & VM35 & VM55 & VM75 & & Linear & Quadratic \\
\hline Supplement intake $\left(\mathrm{g} \mathrm{d}^{-1}\right)$ & 340 & 340 & 330 & 320 & 0.32 & 0.46 & 0.64 \\
\hline Dry matter intake $\left(\mathrm{kg} \mathrm{d}^{-1}\right)$ & 10.19 & 9.43 & 10.41 & 9.11 & 0.73 & 0.40 & 0.65 \\
\hline Initial body weight (kg) & 318 & 311 & 318 & 316 & 2.65 & - & - \\
\hline Final body weight (kg) & 433 & 439 & 441 & 438 & 2.81 & 0.22 & 0.26 \\
\hline Average daily gain $(\mathrm{kg})$ & 1.06 & 1.19 & 1.14 & 1.13 & 0.04 & 0.20 & $0.08^{\mathrm{a}}$ \\
\hline Initial dressing percent (\%) & 51.0 & 51.1 & 50.9 & 51.0 & 0.06 & - & - \\
\hline Final dressing percent (\%) & 53.1 & 53.1 & 54.1 & 52.8 & 0.07 & 0.71 & $<0.01^{\mathrm{b}}$ \\
\hline Carcass gain $\left(\mathrm{kg} \mathrm{d}^{-1}\right)$ & 0.653 & 0.713 & 0.737 & 0.673 & 0.02 & 0.22 & $0.05^{\mathrm{c}}$ \\
\hline Carcass transfer $(\%)^{4}$ & 61.6 & 60.1 & 64.6 & 59.8 & 0.32 & 0.63 & $0.02^{\mathrm{d}}$ \\
\hline
\end{tabular}

${ }^{1} \mathrm{VM} 0=0 \mathrm{mg}$ VM per $100 \mathrm{~kg}$ body weight (BW); VM35 = $35 \mathrm{mg}$ VM per $100 \mathrm{~kg}$ BW; VM55 = 55 mg VM per $100 \mathrm{~kg}$ BW; VM75 $=75 \mathrm{mg}$ VM per $100 \mathrm{~kg}$ BW.

${ }^{2} \mathrm{SEM}=$ Standard error of the mean.

${ }^{3}$ Equations: ${ }^{a)} \mathrm{y}=1.0672+0.004675 \mathrm{x}-0.00005 \mathrm{x}^{2} .{ }^{\mathrm{b})} \mathrm{y}=53.0108+0.02871 \mathrm{x}-0.00039 \mathrm{x}^{2} .{ }^{\mathrm{c})} \mathrm{y}=0.6502+0.003718 \mathrm{x}-0.00004 \mathrm{x}^{2} .{ }^{\mathrm{d})} \mathrm{y}$ $=61.1286+0.06205 \mathrm{x}-0.00088 \mathrm{x}^{2}$. Contrasts significant at $\mathrm{P}<0.05$ and trends were defined as $0.05 \leq \mathrm{P}<0.10$.

${ }^{4}$ Carcass transfer: relationship between carcass gain and body weight gain (adapted from SAMPAIO et al., 2017).

Increasing VM dose did not affect supplement intake $(\mathrm{P}=0.64)$ and dry matter intake $(\mathrm{P}=0.38)$, ruminal $\mathrm{pH}(\mathrm{P}=0.96)$, acetate: propionate ratio $(\mathrm{P}$
$=0.73)$, or total volatile fatty acid $(\mathrm{P}=0.63)$. The concentration of rumen ammonia nitrogen exhibited a quadratic effect $(\mathrm{P}=0.01)$. Among the volatile fatty 
acid, only propionate exhibited a linear behavior ( $\mathrm{P}$ $=0.03$ ), decreasing its concentration as VM doses increased. The acetate presented a trend of quadratic behavior $(\mathrm{P}=0.09)$, with the maximum at the dose of $42 \mathrm{mg}$ VM per $100 \mathrm{~kg}$ BW. The others volatile fatty acid presented a quadratic behavior, with the maximum at doses of 53, 35, 46, and $34 \mathrm{mg} \mathrm{VM}$ per $100 \mathrm{~kg}$ BW for butyrate, valerate, isobutyrate and isovalerate, respectively $(\mathrm{P}<0.01)$. The maximum values were obtained from the equations derived from the treatment results (Table 4).

Table 4. Ammonia nitrogen concentration, ruminal $\mathrm{pH}$, and volatile fatty acids profile of Nellore bulls fed with different doses of virginiamycin (VM) during the growing phase grazing Panicum maximum 'Tanzania' pastures in the rainy season.

\begin{tabular}{|c|c|c|c|c|c|c|c|}
\hline \multirow{2}{*}{ Item $^{1}$} & \multicolumn{4}{|c|}{ Virginiamycin Dose ${ }^{2}$} & \multirow{2}{*}{$\mathrm{SEM}^{3}$} & \multicolumn{2}{|c|}{ Contrasts $^{4}$} \\
\hline & VM0 & VM35 & VM55 & VM75 & & Linear & Quadratic \\
\hline Ammonia nitrogen concentration $\left(\mathrm{mg} \mathrm{dL}^{-1}\right)$ & 8.3 & 9.3 & 10.5 & 8.3 & 0.63 & 0.44 & $0.01^{\mathrm{a}}$ \\
\hline $\mathrm{pH}$ & 6.77 & 6.86 & 6.77 & 6.86 & 0.08 & 0.53 & 0.96 \\
\hline \multicolumn{8}{|l|}{ Volatile fatty acids (mol per $100 \mathrm{~mol}$ ) } \\
\hline Acetate & 75.8 & 75.5 & 75.2 & 75.7 & 0.42 & 0.36 & $0.09^{\mathrm{b}}$ \\
\hline Propionate & 14.8 & 14.2 & 14.2 & 14.3 & 0.31 & $0.03^{\mathrm{c}}$ & 0.13 \\
\hline Butyrate & 7.36 & 7.94 & 8.20 & 7.91 & 0.03 & $<0.01$ & $<0.01^{\mathrm{d}}$ \\
\hline Valerate & 0.62 & 0.65 & 0.67 & 0.63 & 0.02 & 0.21 & $<0.01^{\mathrm{e}}$ \\
\hline Isobutyrate & 0.68 & 0.73 & 0.75 & 0.67 & 0.03 & 0.71 & $0.02^{\mathrm{f}}$ \\
\hline Isovalerate & 0.93 & 1.03 & 0.98 & 0.89 & 0.06 & 0.26 & $<0.01^{\mathrm{g}}$ \\
\hline Acetate: propionate & 5.29 & 5.35 & 5.32 & 5.33 & 0.23 & 0.80 & 0.73 \\
\hline Total volatile fatty acids & 114.9 & 109.8 & 116.3 & 112.5 & 3.48 & 0.85 & 0.66 \\
\hline
\end{tabular}

${ }^{1}$ The ruminal parameters data were obtained from homogenized samples collected at ventral side of the rumen. The mean utilized was from the whole collection time.

${ }^{2} \mathrm{VM} 0=0 \mathrm{mg}$ VM per $100 \mathrm{~kg}$ body weight (BW); VM35 = 35 mg VM per $100 \mathrm{~kg} \mathrm{BW}$; VM55 = 55 mg VM per $100 \mathrm{~kg}$ BW; VM75 $=75 \mathrm{mg}$ VM per $100 \mathrm{~kg} \mathrm{BW}$.

${ }^{3} \mathrm{SEM}=$ Standard error of the mean.

${ }^{4}$ Equations: ${ }^{\text {a) }} \mathrm{y}=8.2253+0.08862 \mathrm{x}-0.00112 \mathrm{x}^{2} .{ }^{\mathrm{b})} \mathrm{y}=75.7801-0.0221 \mathrm{x}+0.000263 \mathrm{x}^{2}{ }^{\mathrm{c})} \mathrm{y}=14.6725-0.00488 \mathrm{x} .{ }^{\mathrm{d})} \mathrm{y}=7.2923+$ $0.02964 \mathrm{x}-0.000028 \mathrm{x}^{2} .{ }^{\mathrm{e})} \mathrm{y}=0.6229+0.002102 \mathrm{x}-0.00003 \mathrm{x}^{2} .{ }^{\mathrm{ff}} \mathrm{y}=0.6752+0.002765 \mathrm{x}-0.00003 \mathrm{x}^{2} .{ }^{\mathrm{g})} \mathrm{y}=0.9269+0.005393 \mathrm{x}-$ $0.00008 \mathrm{x}^{2}$. Contrasts significant at $\mathrm{P}<0.05$ and trends were defined as $0.05 \leq \mathrm{P}<0.10$.

\section{Discussion}

Virginiamycin had no effect on the intake of protein supplements (provided in the amount of $1 \mathrm{~g}$ $\mathrm{kg} \mathrm{BW}^{-1}$ per day). This ensured that the doses of VM that were studied were properly ingested even when given in very high amounts, as in dose of $75 \mathrm{mg} \mathrm{VM}$ per $100 \mathrm{~kg} \mathrm{BW}$. Additionally, such effect indicated that protein supplements (provided in the amount of $1 \mathrm{~g} \mathrm{~kg} \mathrm{BW}^{-1}$ per day) may be used as a vehicle for providing additives and/or growth promoters in grazing systems to growing Nellore bulls. At the same time, dry matter intake was not influenced by VM provided for grazing animal.

To determine the optimal VM dose, ruminal parameters and performance responses were evaluated. In this study, the rumen ammonia nitrogen had a quadratic behavior, as performance parameters. For animals reared on pasture, production of rumen ammonia nitrogen can help explained the performance. This occurs because in high-forage diets, the increased availability of rumen ammonia nitrogen improves the production of 
microbial enzymes, since fibrolytic microorganisms preferentially use this compound as a precursor for the synthesis of amino acids (DETMANN et al., 2014). In feedlots, VM reduces the concentration of ruminal ammonia (GUO et al., 2010), because it can inhibit the activity of bacteria producing ammonia (GUO et al., 2010), which are characterized by high deaminase activity.

Its inhibition is therefore associated with amino acid economy from ruminal degradation and, consequently, with greater efficiency of protein utilization in the post-ruminal phase. The previously reported pattern of ammonia production that is characterized by a reduced amino acid degradation in the rumen and a decreased production of rumen ammonia nitrogen (GUO et al., 2010) was not observed in this study. However, the use of VM on pasture resulting in an increase in ammonia production can be positive. These contradictory results may be due to the differences in nitrogen profile between feedlot and pasture diets.

Another indication of increased amino acid deamination, besides the optimal dose-response and consequent increased production of ammonia, is the quadratic behavior observed for volatile fatty acid such as valerate, isobutyrate and isovalerate, which are produced by amino acid degradation in the rumen (ZHANG et al., 2013). In addition, maximum passage of dietary protein from the rumen to the intestine occurs when the relationship of CP to digestible organic matter (DOM) is 160 g CP per kg DOM (POPPI; MCLENNAN, 1995), a value greater than that found in this study (141 g CP per kg DOM). Given that during the rainy season the amount of organic material increases considerably, a significant increase in nitrogen is needed to sustain microbial growth (DETMANN et al., 2014). The imbalance between protein and energy availability in the rumen reduces the efficiency in the utilization of metabolizable energy and limits the intake due to heat production caused by excess energy (POPPI; MCLENNAN, 1995) and decreasing the performance. The dose of VM that maximizes substrate availability for fibrolytic bacteria may promote better feed utilization and greater efficiency in the use of available energy.

The improvements in fiber efficiency were likely responsible for the increase in bacterial populations producing butyrate, such as Butyrivibrio, which can be suppressed with high-energy diets (LI et al., 2012). Such behavior led to a greater proportion of this acid approaching the dose that maximized performance. Along with the production of ammonia, the production of butyrate may help to explain the improved performance, since VM did not affect the acetate: propionate ratio. Butyrate plays a role in intestinal physiology and health, and greater levels in the gastrointestinal tract can positively affect the efficiency of nutrient utilization (LI et al., 2012). Butyrate is the main energy source for ruminal epithelial cells, and its increased production may increase the surface absorption of nutrients. Moreover, it has numerous regulatory effects on cells, such as differentiation, motility, induction of apoptosis, and inhibition of proliferation (LI et al., 2012). All these effects may safe energy and increase nutrient use efficiency. The maximum dose for the production of butyrate was $53 \mathrm{mg}$ VM per $100 \mathrm{~kg} \mathrm{BW}$, above the dose that maximized the performance of the animals (47 mg VM per $100 \mathrm{~kg}$ BW).

These results contribute to future studies and production chain by providing a preliminary understanding of the optimal dose-response to VM that maximizes the performance of animals reared on pasture. Further studies should examine the differences existing in the use of VM in different production systems such as pasture and feedlot. Studies are also required to show possible modulation in forage degradation rate induced by $\mathrm{VM}$ as well as changes in passage rate, microbial protein production, and post-ruminal absorption. This may clarify the differences observed in the mechanism of action of VM in ruminants in different production systems (pasture and feedlot). 


\section{Conclusion}

The optimum dose of VM for Nellore bulls supplemented during the growing phase in the rainy season is $47 \mathrm{mg} 100$ per $\mathrm{kg} \mathrm{BW}$ due the greater performance.

\section{Acknowledgements}

We would like to thank the Phibro Animal Health Corporation, Connan Animal Nutrition, and São Paulo Research Foundation (FAPESP, grant \#2011/02937-4, grant \#2013/10340-3, grant \#2016/01961-2).

\section{References}

ASSOCIATION OF OFFICIAL ANALYTICAL CHEMISTS - AOAC. Official methods of analysis. $16^{\text {th }}$ ed. Washington: AOAC, 1995.

BENATTI, J. B.; ALVES NETO, J. A.; OLIVEIRA, I. M.; RESENDE, F. D.; SIQUEIRA, G. R. Effect of increasing monensin sodium levels in diets with virginiamycin on the finishing of Nellore cattle. Animal Science Journal, Medford, v. 88, n. 11, p. 1709-1714, 2017.

BERNDT, A.; TOMKINS, N. W. Measurement and mitigation of methane emissions from beef cattle in tropical grazing systems: a perspective from Australia and Brazil. Animal, Cambridge, v. 7, n. s2, p. 367-372, 2013.

CONSELHO NACIONAL DE CONTROLE DE EXPERIMENTAÇÃO ANIMAL - CONCEA. Diretriz Brasileira para o cuidado e a utilização de animais para fins científicos e didáticos. Resolução Normativa $\mathrm{n}^{\circ} 12$ de 20 de set. 2013. Brasília: MCTI, 2013. Disponível em: $\quad<$ http://www.clp.unesp.br/Home/AreaTecnica Academica/diretrizes-concea-2013.pdf $>$. Acesso em: 20 022018.

DE VRIES, M. F. W. Estimating forage intake and quality in grazing cattle: A reconsideration of the hand-plucking method. Journal of Range Management, Tucson, v. 48, n. 4, p. 370-375, 1995.

DETMANN, E.; PAULINO, M. F.; VALADARES FILHO, S. C.; HUHTANEN, P. Nutritional aspects applied to grazing cattle in the tropics: a review based on Brazilian results. Semina: Ciências Agrárias, Londrina, v. 35, n. 4, p. 2829-2854, 2014.

ERWIN, E. S.; MARCO, G. J.; EMERY, E. M. Volatile fatty acid analyses of blood and rumen fluid gas chromatography. Journal of Dairy Science, Champaign, v. 44, n. 9, p. 1768-1771, 1961.

FIEMS, L. O.; BOUCQUE, C. V.; COTTYN, B. G.; MOERMANS, R. J.; BRABANDER, D. L. de. Effect of virginiamycin supplementation on the performance of young grazing cattle. Grass and Forage Science, Nantwich, v. 47, n. 1, p. 36-41, 1992.

GOERING, H. K.; VAN SOEST, P. J. Forage fiber analysis: apparatus, reagents, procedures and some applications. Washington: U.S. Agricultural Research Service, $1970.379 \mathrm{p}$.

GOULART, R. C. D. Avaliação de antimicrobianos como promotores de crescimento via mistura mineral para bovinos de corte em pastejo. 2010. Tese (Doutorado em Ciências) - Universidade de São Paulo, Piracicaba.

GUO, T. J.; WANG, J. Q.; BU, D. P.; LIU, K. L.; WANG, J. P.; LI, D.; LUAN, S. Y.; HUO, X. K. Evaluation of the microbial population in ruminal fluid using real time PCR in steers treated with virginiamycin. Czech Journal of Animal Science, Praga, v. 55, n. 7, p. 276-285, 2010.

LI, R. W.; WU, S.; BALDWIN VI, R. L.; LI, W.; LI, C. Perturbation dynamics of the rumen microbiota in response to exogenous butyrate. PLOS ONE, San Francisco, v. 7, n. 1, p. 1-11, 2012.

MCMANUS, C.; BARCELLOS, J. O. J.; FORMENTON, B. K.; HERMUCHE, P. M.; CARVALHO, O. A. D.; GUIMARÃES JÚNIOR, R. F.; GIANEZINI, M.; DIAS, E. A.; LAMPERT, V. N.; ZAGO, D.; BRACCINI NETO, J. Dynamics of cattle production in Brazil. PLoS ONE, California, v. 11, n. 1, p. 1-15, 2016.

MOREIRA, A. D.; SIQUEIRA, G. R.; LAGE, J. F.; BENATTI, J. M. B.; MORETTI, M. H.; MIGUEL, M. H.; OLIVEIRA, I. M.; RESENDE, F. D. Castration methods in crossbred cattle raised on tropical pasture. Animal Production Science, Clayton, p. 1-9, 2017.

MORETTI, M. H.; FLÁVIO, D. R.; SIQUEIRA, G. R.; ROTH, A. P. T. P.; CUSTÓDIO, L.; ROTH, M. T. P.; CAMPOS, W. C.; FERREIRA, L. H. Performance of Nellore young bulls on Marandu grass pasture with protein supplementation. Revista Brasileira de Zootecnia, Viçosa, MG, v. 42, n. 6, p. 438-446, 2013.

POPPI, D. P.; MCLENNAN, S. R. Protein and energy utilization by ruminants at pasture. Journal of Animal Science, Champaign, v. 73, n. 1, p. 278-290, 1995.

ROBERTSON, J. B.; VAN SOEST, P. J. The detergent system of analysis and its application to human foods. In: JAMES, W. P. T.; THEANDER, O. (Ed.). The analysis of dietary fiber in foods. New York: Marcel Dekker Press, 1981. p. 123-158. 
ROGERS, J. A.; BRANINE, M. E.; MILLER, C. R.; WRAY, M. I.; BARTLE, S. J.; PRESTON, R. L.; GIL, D. R.; PRITCHARD, R. H.; STILBORN, R. P.; BECHTOL, D. T. Effects of dietary virginiamycin on performance and liver abscess effects of dietary virginiamycin incidence in feedlot cattle. Journal of Animal Science, Champaign, v. 73, n. 1, p. 9-20, 1995.

ROTH, M. T. P.; RESENDE, F. D.; SIQUEIRA, G. R.; FERNANDES, R. M.; CUSTÓDIO, L.; ROTH, A. P. T. P.; MORETTI, M. H.; CAMPOS, W. C. Supplementation of Nellore young bulls on Marandu grass pastures in the dry period of the year. Revista Brasileira de Zootecnia, Viçosa, MG, v. 42, n. 6, p. 447-455, 2013.

SAMPAIO, R. L.; RESENDE, F. D.; REIS, R. A.; OLIVEIRA, I. M.; CUSTÓDIO, L.; FERNANDES, R. M.; PAZDIORA, R. D.; SIQUEIRA, G. R. The nutritional interrelationship between the growing and finishing phases in crossbred cattle raised in a tropical system. Tropical Animal Health and Production, Edinburgh, v. 49, n. 5, p. 1015-1024, 2017.

SANTANA, M. C. A.; FIORENTINI, G.; MESSANA, J. D.; DIAN, P. H. M.; CANESIN, R. C.; REIS, R. A.; BERCHIELLI, T. T. Different forms and frequencies of soybean oil supplementation do not alter rumen fermentation in grazing heifers. Animal Production Science, Clayton, v. 57, n. 3, p. 530-538, 2017.

SANTANA, M. C. A.; VIEIRA, B. R.; COSTA, D. F.; DIAN, P. H. M.; FIORENTINI, G.; CANESIN, R. C.; PEREIRA, G. T.; REIS, R. A.; BERCHIELLI, T. T. Source and frequency of dry season lipid supplementation of grazing, finishing cattle. Animal Production Science, Clayton, v. 55, n. 6, p. 745-751, 2015.

SOLLENBERGER, L. E.; CHERNEY, D. J. Evaluating forage production and quality. In: BARNES, R. F.; MILLER, D. A.; NELSON, C. J. (Ed.). Forages: the science of grassland agriculture. Iowa: Iowa State University Press, 1995. p. 97-110.

VALENTE, T. N. P.; DETMANN, E.; QUEIROZ, A. C.; VALADARES FILHO, S. C.; GOMES, D. I.; FIGUEIRAS, J. F. Evaluation of ruminal degradation profiles of forages using bags made from different textiles. Revista Brasileira de Zootecnia, Viçosa, MG, v. 40, n. 11, p. 2565-2573, 2011.

VAN SOEST, P. J.; ROBERTSON, J. B. Analysis of forages and fibrous foods. Ithaca: Cornell University Press, 1985. 202 p.

WEATHERBURN, M. W. Phenol-hypochlorite reaction for determination of ammonia. Analytical Chemistry, Champaign, v. 39, n. 8, p. 971-974, 1967.

WILLIAMS, C. H.; DAVID, D. J.; IISMAA, O. The determination of chromic oxide in faeces samples by atomic absorption spectrophotometry. Journal Agricultural Science, Toronto, v. 59, n. 3, p. 381-385, 1962.

ZHANG, H. L.; CHEN, Y.; XU, X. L.; YANG, Y. X. Effects of branched-chain amino acids on in vitro ruminal fermentation of wheat straw. Asian-Australasian Journal of Animal Sciences, Gwanak-gu, v. 26, n. 4, p. 523-528, 2013. 